\title{
A year in the life of the streptococcus
}

\author{
ET Mosley ${ }^{1 *}$, AM McMahon ${ }^{1,2}$, F Shackley $^{1}$, C Waruiru $^{1}$ \\ From 18th Pediatric Rheumatology European Society (PReS) Congress \\ Bruges, Belgium. 14-18 September 2011
}

\section{Background}

Mild streptococcal infections infection are extremely common, however invasive infections can lead to high mortality rates. Described in 1982, post streptococcal reactive arthritis (PSRA) has been reported with increasing frequency.

\section{Aim}

We aimed to look at the number of children presenting to a Tertiary Children's Hospital, with serological significant streptococcal illnesses, diagnoses and antibiotic treatment of those patients.

\section{Method}

Over a One year period of ASOT ( anti streptolysin O) results from a tertiary Children's Hospital were reviewed. The ASOT results documented, paired data of ASOT \& Anti DNase B (anti Deoxyribonuclease B antibodies) reviewed for correlation. Diagnoses were obtained using clinical notes.

Throat swabs results were reviewed where performed. The antibiotic treatment advised documented.

\section{Results}

ASOT January 2009- December $2010=645$

$\mathrm{N}^{\circ}$ patients $=359$

$\mathrm{N}^{\circ}$ ASOT's $>400=100(28 \%)$

Notes reviewed $=95 / 100$ patients

Where both ASOT and Anti DNAse B were performed simultaneously (No $=194)$, results correlated in $88 \%$

Throat Swab performed in the group with ASOT $>400$ $=43 / 100$

$65 \%$ patients with ASOT $>400$ were prescribed antibiotics

\begin{tabular}{ll}
\hline Diagnosis by System & Number of patients \\
\hline Rheumatology & 18 \\
\hline Dermatology & 18 \\
\hline ENT & 17 \\
\hline Respiratory & 12 \\
\hline Infectious diseases & 11 \\
\hline Nephrology & 8 \\
\hline Neurology & 5 \\
\hline Chronic Fatigue & 3 \\
\hline Gastroenterology & 2 \\
\hline Cardiac & 1 \\
\hline
\end{tabular}

\begin{tabular}{ll}
\hline Rheumatological Diagnosis & Number (18/95) \\
\hline Juvenile idiopathic arthritis & 4 \\
\hline Systemic Onset Juvenile Ideopathic arthritis & 2 \\
\hline Post streptococcal Reactive Arthritis & 3 \\
\hline Vasculitis & 5 \\
\hline Kawasaki & 2 \\
\hline Periodic Fever & 2 \\
\hline
\end{tabular}

\section{Conclusions}

Nearly $1 / 5$ of patients with positive streptococcal serology had a rheumatological diagnosis, suggesting it is a significant trigger in rheumatological conditions.

This study highlights vigilance and alertness that patients with Streptococcal Infections may evolve or contribute to the development of a rheumatogical condition.

There is a need for a consensus opinion on treatment and eradication of streptococcal infection.

\section{Author details}

'Sheffield Children's Hospital, Sheffield, UK. ²Leeds Children's Hospital, Leeds, UK.

\footnotetext{
${ }^{1}$ Sheffield Children's Hospital, Sheffield, UK

Full list of author information is available at the end of the article
}

Correspondence: ellen.mosley@sch.nhs.uk 
- Convenient online submission

- Thorough peer review

- No space constraints or color figure charges

- Immediate publication on acceptance

- Inclusion in PubMed, CAS, Scopus and Google Scholar

- Research which is freely available for redistribution 